\title{
European Social Fund: Evolution and geographic allocation. The case of Spain
}

\author{
Juan González Alegre \\ Universidad Autónoma de Barcelona \\ y Universidad de Málaga
}

\begin{abstract}
The European Social Fund (ESF) is the fiscal tool used by the European Union to undertake labor market policies. It is devoted mainly to the promotion of Active Labor Market Policies (ALMPS) in regions in which the performance of the labor market is relatively poor. This paper analyzes the evolution of the ESF since its creation, and its capacity of adaptation to renewed strategies and a changing scenario. With a particular attention to the case of Spain, the paper also reviews the empirical literature, in the search of scientific evidence about the capacity of ALMPs to raise employment.
\end{abstract}

Keywords: Active Labour Market Policies, European Social Fund, Intergovernmental relations.

JEL classification: H53, H77, JO.

\section{Resumen}

El Fondo Social Europeo (FSE) es el instrumento fiscal de la Unión Europea para la ejecución de políticas laborales. Está orientado, principalmente, al incentivo de Políticas Activas de Empleo en regiones con deficiencias en su mercado de trabajo. Este trabajo analiza la evolución del FSE desde su creación, y su capacidad para adaptarse tanto a las nuevas estrategias de política regional como a la coyuntura económica. Prestando una atención especial al caso particular de España, el trabajo también incluye una mención a la evidencia empírica existente sobre la eficacia de las Políticas Activas de Empleo.

Palabras clave: Políticas Activas de Empleo, Fondo Social Europeo, relaciones intergubernamentales.

Clasificación JEL: H53, H77, JO.

\section{Introduction}

The level of unemployment in the European Union, which has traditionally been larger in comparison to other regions of the world, has grown above socially acceptable levels during the recent recession episode. The average unemployment rate lies above ten percent in many member states, remaining persistently high over the last years with a rising gap between countries with healthier economies and countries lagging behind. There also other asymmetries, such as the intergenerational situations that create large levels of unemployment particularly in younger cohorts is some countries, as well as the abnormal large level of unfilled vacancies. 
The main fiscal tool available in the European Union to tackle this problem has traditionally been the European Social Fund, in the framework of the Structural Funds. In fact, the European Council has recently presented the, so called, Youth Employment Initiative, intended to support young unemployed citizens in regions with particularly high level of youth unemployment rate (above 25\%). This policy measure will increase around $€ 3$ billion the budget of the European Social Fund (ESF) for the period 2014-2020.

In fact, the importance of the ESF has been steadily rising over the years, since its creation, together with the signature of the Treaty of Rome. The ESF promotes, mainly, expenditure in projects related to Active Labour Market Policies (ALPM), as well as other policies assisting workers. The subsequent reforms that the Structural Funds have experienced in the last decades increase the level of cooperation and coordination between levels of the public administration. The rules governing the distribution and implementation of the ESF are in continuous adaptation to a changing environment, such as the inclusion of new member states in the European Union (EU) or the episodes of fiscal decentralization.

Spain, in particular, has been one of the main beneficiaries of the ESF since its entrance in the EU in 1986, due to the relative poor performance of its labour market. After the enlargement of the EU in 2004, some priorities of the Structural Actions were focused to the new member states. Nevertheless, the labour market problems in Spain, as well as in other peripheral countries, are still far from being solved. In this scenario, it gets difficult to disentangle to which extent the ESF has been useful in its purpose of creating a more flexible and efficient labour market, and in which the particular policies and regions in which the efforts should be focused in the next years.

This paper describes the evolution of the ESF since its creation. It underlines the main figures and rules governing its allocation in particular policies and geographical areas. The evolution of the economic environment and the strategic purposes of the subsequent programming periods of the Regional Policy have inspired several reforms on the Structural Funds, whose main guidelines are described here. The study puts, then, particular attention to the case of Spain. As Spain has experience a process of fiscal decentralization in the last decades, the paper also includes a concise analysis of how this transfer of fiscal autonomy might have affected the vertical distribution of ESF transfers. Finally, and with the purpose of illustrating to which extent there is evidence of the capacity of ALMPs to increasing employment, there is a breviloquent review of the main empirical results estimating that relationship, both at the national and the regional level.

The paper is organized as follows: Section 2 shows the main figures governing the evolution of the European Social Fund since its creation, from a fiscal perspective. It also includes a chronological description of the main reforms of its distributive regulation. Section 3 illustrates evolution of the ESF in Spain from regional data, putting a particular attention to its link with the process of fiscal decentralization in subsection 3.1; Section 4 describes the econometric evidence found in studies 
using panel-data models to analyze the impact of ALMPs on unemployment, with subsection 4.a focusing on studies using regional-level data; and Section 5 concludes.

\section{The European Social Fund as a fiscal tool}

The European Social Fund (ESF) is the oldest of the Structural Funds and its creation was stated in the Treaty of Rome in 1957, with the original task of promoting within the Community employment facilities and the geographical and occupational mobility of workers. The ESF was founded upon the principles of its predecessor in the European Coal and Steel Community, the Fund for the Retraining and Resettlement of Workers. During its first two decades, due to the low levels of unemployment in the European Economic Community, the ESF was devoted to facilitate migration of workers and to retrain people who had suffered accidents at work $^{1}$. The importance of the European Social Fund on the European Communities budget was fairly minor during this period, representing around $1 \%$ of the total budget and less than $0.01 \%$ of $\mathrm{GDP}^{2}$.

FIGURE 1

\section{THE SHARE PF THE STRUCTURAL FUNDS IN THE EUROPEAN BUDGET}

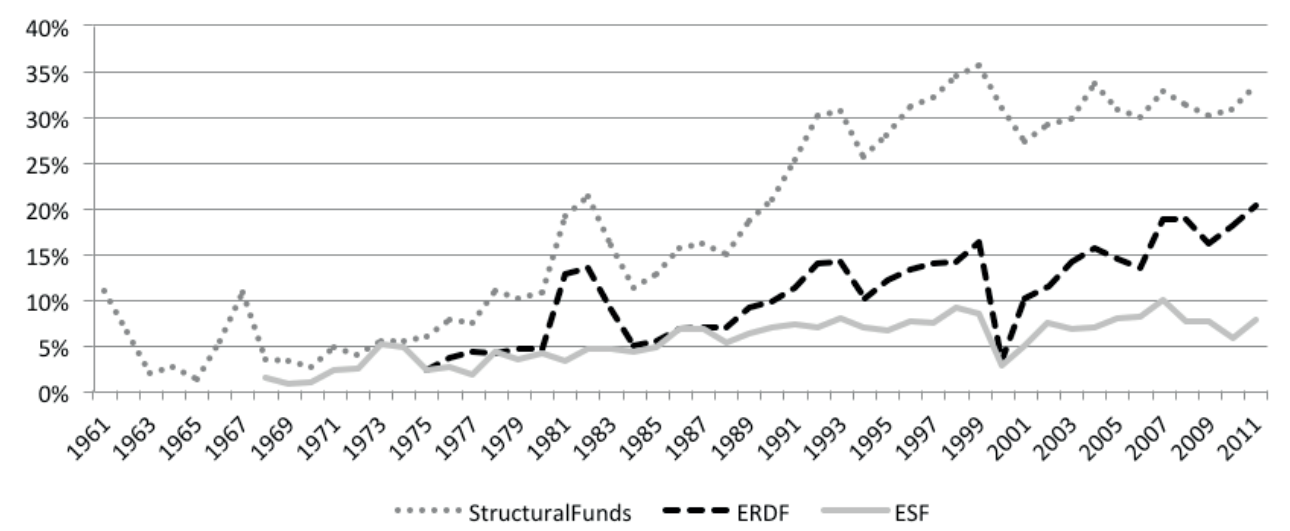

SOURCE: EU budget financial report (several years)..

1 European Commission (2007).

2 The Structural Funds represented altogether around 5\% of the total European Communities budget during the sixties (European Communities, 2009), which in turn represented around 0.5\% of the GDP of the 6 member states. 
The first reform of the ESF in 1971, increased notably the size of the Fund and intended to target the funding towards particular groups and categories of people. The Fund was therefore, oriented towards two types of intervention: regions with particular difficulties due to restructuring or industrial change caused by Community policies and less developed regions. In 1975 was created the European Regional Development Fund devoted to promote infrastructure in regions lagging behind. The ESF and ERDF were referred to as "Structural Funds". Although the next reform was foreseen for the early eighties, the deterioration in the employment situation led to prior amendments of the rules governing the ESF in 1977 and 1978, giving increasing attention to less developed regions and including additional aid to some population groups in risk of exclusion from the labor market.

FIGURE 2

THE ALLOCATION OF THE ESF: 1974-1982. DISTRIBUTION AMONG MEMBER STATES AND AVERAGE ANNUAL ALLOCATION PER INHABITANT (In per capita $\mathrm{ECU}$ )
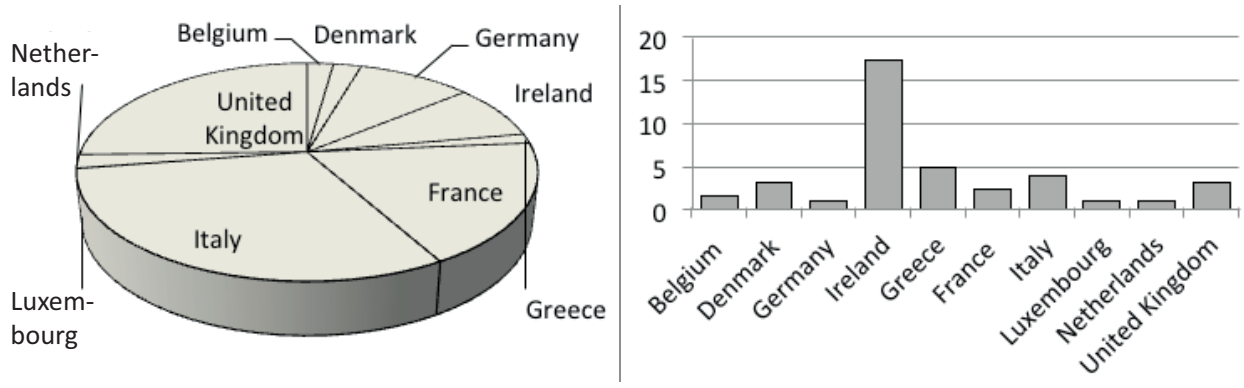

SOURCE: Commission of the European Communities (1983), Report and proposals on ways of increasing the effectiveness of the Community's structural Funds, Brussels, OPOCE COM (83) 501 (Commitments).

At the beginning, Member States implemented projects that were re-funded afterwards, but, as access to Fund started to cover wider policy areas, a system of prior approval was put in place. Still, until the 1988 reform, there was little supranational influence over the particular projects and implementation of the ESF and the other funds (Bache et al., 2011). Although in absolute terms Italy, the United Kingdom and France were the main beneficiaries of the allocation of the ESF during these years, the allocation of funds per inhabitant were clearly focused towards Ireland whose advantage over the other Member States was remarkable.

In the eighties, following the 1979 energy crisis, with unemployment arising as a severe problem -in particular youth unemployment- and some regions in the need of industrial or agricultural reconversion, the ESF was reformed in order to include workers 
from all areas of the economy. In the view of the economic disequilibria emerging from the accession of the three new Member States of the eighties, in 1983 it was decided that funding from the ESF should be focused on the assistance to poorer regions in order to reduce the imbalances within the European Union (European Commission, 1998; 2007).

\section{FIGURE 3}

\section{THE ALLOCATION OF THE ESF: 1984-1987. DISTRIBUTION AMONG MEMBER STATES AND AVERAGE ANNUAL ALLOCATION PER INHABITANT (In per capita ECU)}
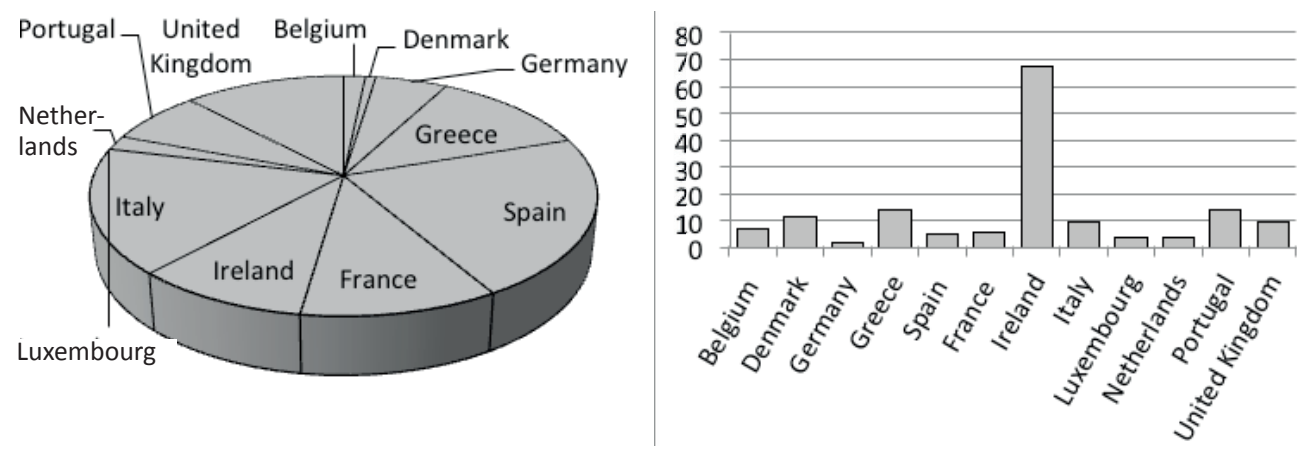

SOURCE: Commission of the European Communitites (1989), Guide to the reform of the Community's structural Funds, OPOCE: Brussels ISBN: 92-826-0029-7 (Commitments)

The size of the Fund was consequently enlarged, as Portugal and Greece became quickly among the main recipient states, with Ireland still receiving an outstanding per capita contribution in comparison to the remaining Member States.

The ESF was substantially reformed in 1988, together with the other Structural Funds, with the purpose of moving from individual projects to multiannual partnerships between the Member States and the Commission. This reform also included an increase on the financial weight of the ESF. The new approach was built on four basic principles: Concentration, which was applied in various ways, such as in determined regions or policy objectives; partnership, with national, regional or local authorities; programming, involving national and regional authorities together with the European Commission and setting the priorities and allocation for each period (5-7 years); and additionality, as the funds were not intended to replace but to increase national funds. 
FIGURE 4

THE ALLOCATION OF THE ESF: PROGRAMMING PERIOD 1989-1993. DISTRIBUTION AMONG MEMBER STATES AND AVERAGE ANNUAL ALLOCATION PER INHABITANT (In per capita ECU)
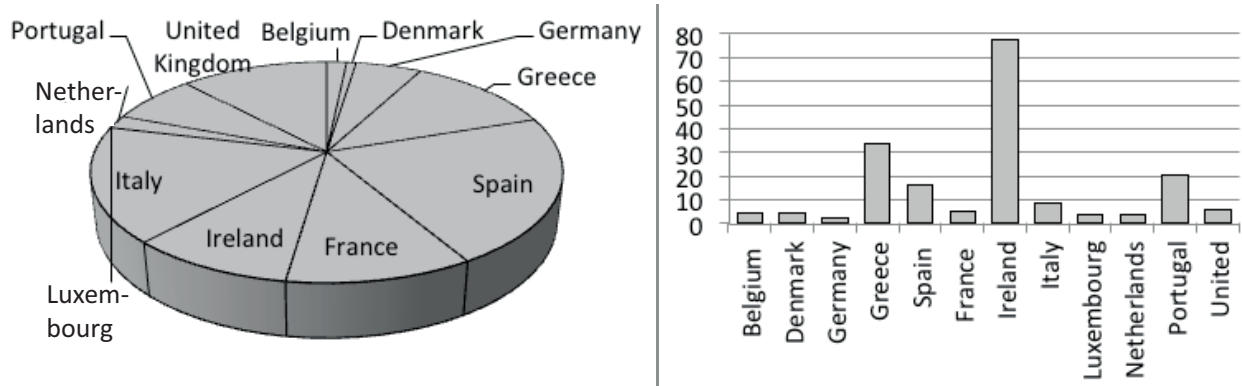

SOURCE: Commission of the European Communitites (1990), Annual report on the implementation of the reform of the Structural Funds 1989, Brussels EC (COM(90) 516 final). (Initial allocation of funds.)

In 1992 the single market had reached its completion and the way towards the single currency was clearer. Nevertheless, unemployment had resumed its upward trend after the some steady years in the late eighties. The review of the Structural Funds in 1993 was focused towards strengthening economic and social cohesion, and the budget for the Structural Funds was almost doubled for the period 1994-1999 in comparison to the period 1988-1993. The Cohesion Fund was introduced to help poorer EU countries in developing infrastructures, while the Financial Instrument of Fisheries Guidance (FIFG) targeted restructuring in the fisheries sector. The European Agricultural Guidance and Guarantee Fund (EAGGF), in existence since 1962, invested in the development of the agricultural sector. The ESF was targeted to increasing competitiveness and preventing unemployment through education and training activities focused on workers with higher risk of exclusion, such as young job-seekers or long-term unemployed, within the framework of the Commission's White paper on Growth, Competitiveness and Employment. 


\section{FIGURE 5}

\section{THE ALLOCATION OF THE ESF: PROGRAMMING PERIOD 1994-1998. DISTRIBUTION AMONG MEMBER STATES AND AVERAGE ANNUAL ALLOCATION PER INHABITANT}

(In per capita Euro)
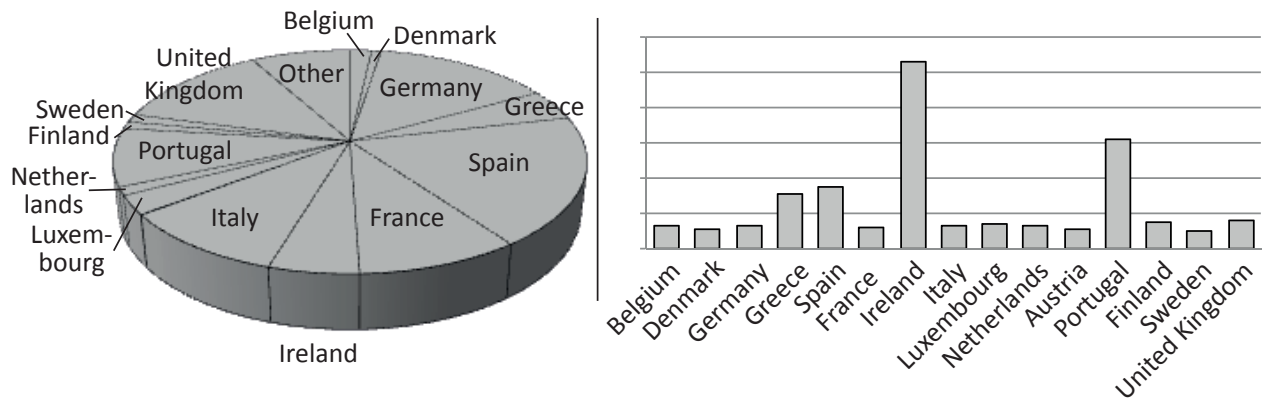

SOURCE: European Commission (1999), The Structural Funds in 1998 Tenth annual report, OPOCE: Brussels $\operatorname{COM}(99) 467$ final (Commitments).

The ESF was geared towards supporting the European Employment Strategy as a part of the Lisbon Strategy at the beginning of the twenty first century. The ESF would then target the four pillars of the European Employment Strategy: enhancing the skills and flexibility of the workforce; development of active labor market measures in order to prevent youth long-term unemployment; development of small and medium sized enterprises by enhancing entrepreneurship potential; and promote equal opportunity and prevent social exclusion within the labor market.

\section{FIGURE 6}

THE ALLOCATION OF THE ESF: PROGRAMMING PERIOD 2000-2006. DISTRIBUTION AMONG MEMBER STATES AND AVERAGE ANNUAL ALLOCATION PER INHABITANT (In per capita euro)
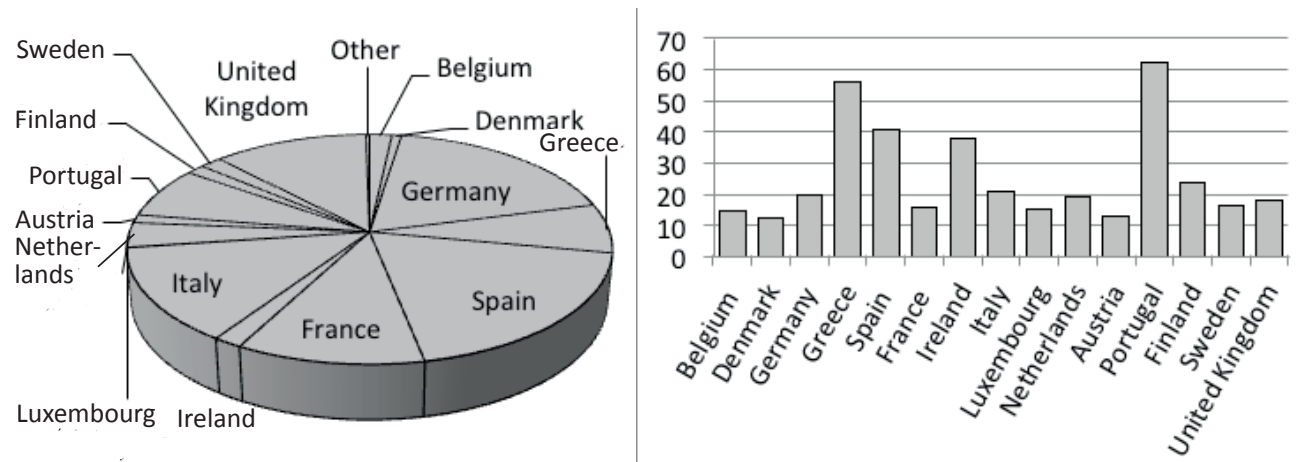

SOURCE: Commission of the European Communities (2004), 15th Annual report on the implementation of the Structural Funds 2003, Brussels COM(2004) 721 final (Initial allocations). 
The programming period 20072013 includes substantial reorganization of the Cohesion Policy. The former EAGGF and FIFG, now replaced by the European Agricultural Fund for Rural Development (EAFRD) and the Financial Instruments for Fisheries Guidance (FIFG) respectively, are no longer involved in the cohesion policy, while the Cohesion Fund will participate in the Convergence objective instead of functioning independently as it did before. The rules have been simplified and the Funds are targeted specifically towards the promotion of competitiveness and employment creation. The link of the ESF with the European Employment Strategy is strengthened and the Fund priorities are centered in convergence and employment objectives (European Commission, 2007b).

\section{FIGURE 7}

THE ALLOCATION OF THE ESF: PROGRAMMING PERIOD 2007-2013. DISTRIBUTION AMONG MEMBER STATES AND AVERAGE ANNUAL ALLOCATION PER INHABITANT (In per capita Euro)
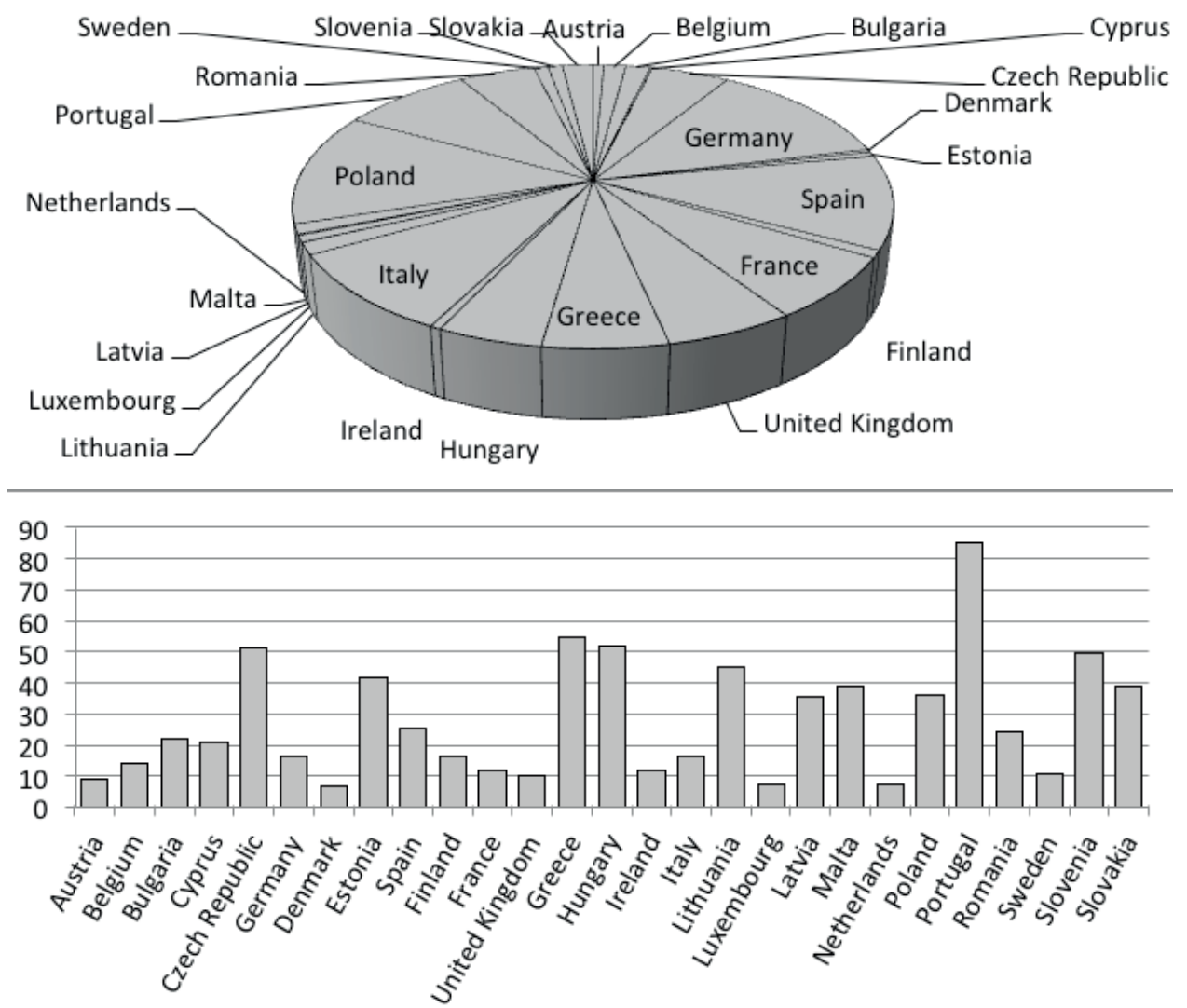

SOURCE: ESF Database portal at http://ec.europa.eu/esf/main.jsp?catId=440\&langId=en\#opt1 (ESF Initial financial allocations as at 31.12.2007) 
In sum, the European Social Fund has increased notably its presence in the European economy, not only through its raising presence in the EU budget, as shown in Figure 1, but mostly as its importance on the total European economy has followed a slow but steady upward trend. The European Social Fund allocates today over 13 trillion Euro, representing on average around $0.07 \%$ of the European economy.

FIGURE 8

\section{EVOLUTION OF THE EUROPEAN STRUCTURAL FUNDS (AS A SHARE OF GDP IN THE EUROPEAN COMMUNITIES/EUROPEAN UNION)}

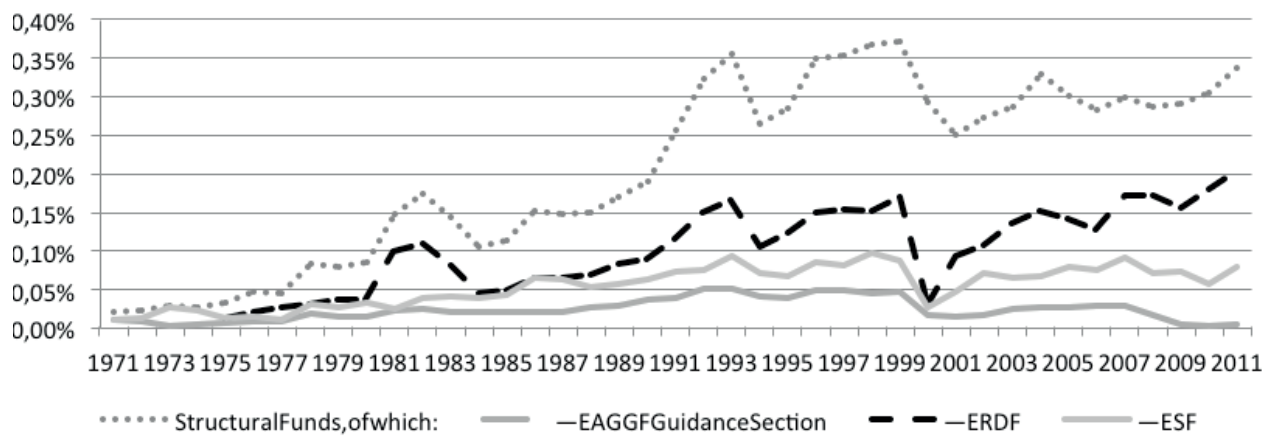

SOURCE: Self elaborated from data in: EU budget (several years) Financial Report, Eurostat and OECD.

The chart above illustrates how this trend has been common to other Structural Actions, which in aggregate have raised to represent -inclusive of the Cohesion Fund- near half a percentage point over total GDP during the last two decades.

\section{The distribution of the European Social Fund in Spain, a regional perspective}

Spain joins the European Communities in 1986, simultaneously to Portugal. In contrast to the ERDF, there was no "a priori" distribution of the ESF among Member States (apart from the fact that part of the budget was reserved for "absolute priority" territories, which included Greece, Portugal, Ireland, Northern Ireland, the French overseas territories, the Italian Mezzogiorno, and 7 Spanish Autonomous regions -Andalusia, Canary Islands, Castile and Leon, Castile La Mancha, Extremadura, Galicia and Murcia) plus Ceuta and Melilla) in these years. In addition, the projects were submitted by the Member states and evaluated by the European Commission individually. Therefore, the final allocation of the ESF during these years is greatly a consequence of the absorptive capacity of the public administration. (Dominguez González, 1989). 
FIGURE 9

\section{DISTRIBUTION OF THE EUROPEAN STRUCTURAL FUNDS AMONG SPANISH REGIONS}

(1986-1988)
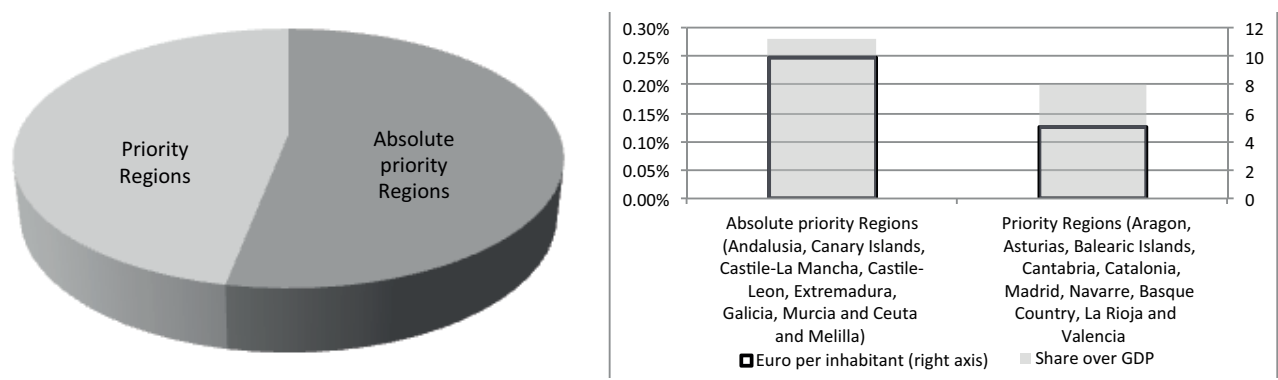

SOURCE: DOMINGUEZ GONZALEZ (1989). "El fondo social europeo y España”, Política social y comunitaria, no. 4-5 and INE (Spanish National Statistical Office).

Seven over the seventeen Spanish regions were considered "absolute Priority" regions in 1986 in line with the regulations of the ESF. The ten remaining regions were considered "Priority" regions, which also entitled them to access the ESF funds due to high unemployment rates or economic restructuring.

FIGURE 10

\section{DISTRIBUTION OF THE EUROPEAN STRUCTURAL FUNDS AMONG SPANISH REGIONS \\ (Programming period 1989-1993)}
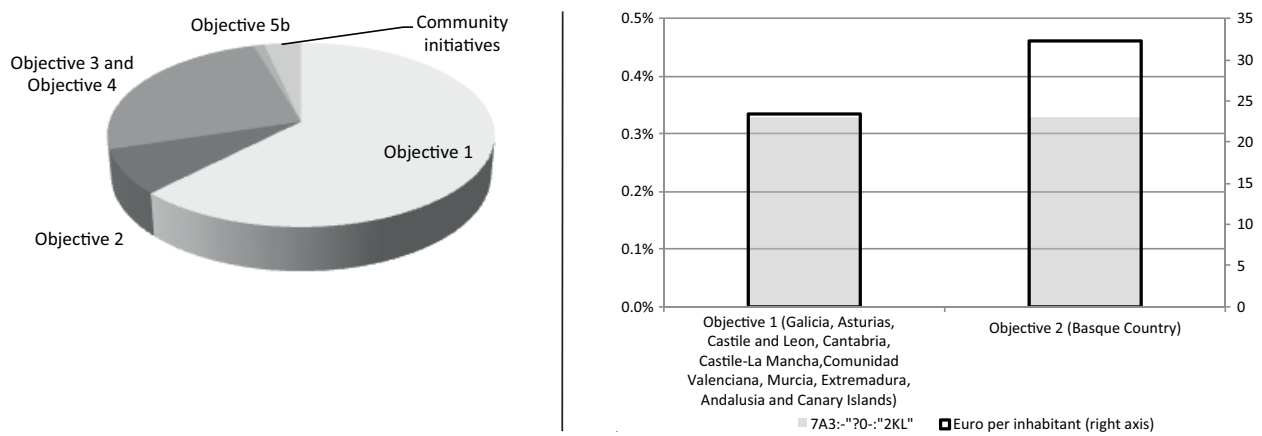

SOURCE: 5th annual report on the implementation of the reform of the Structural Funds (1993) and INE. 
The programming period 1989-1993 included a new classification of the European territory according to the targeted objective of the Structural Funds, being the Objective 1 regions equivalent to the former AR regions representing less developed areas inside the community. The objective 2 regions were those suffering process of reconversion due to industrial decline. The objective 3 was to fight against longterm unemployment while the objective 4 was to promote the inclusion of young people in the labor market. Finally, objective 5 was targeted to the development of rural areas. The European Social Fund was the only one of the Structural Funds that would participate in the development of all five objectives.

The aid would no longer be distributed through individual applications, but the Member States will now propose multiannual plans to the European Commission which include the use of all Structural funds in their territory. Ten Spanish regions were considered objective 1 for this programming period, while one region was considered objective 2 .

FIGURE 11

DISTRIBUTION OF THE EUROPEAN STRUCTURAL FUNDS AMONG SPANISH REGIONS

(Programming period 1994-1999)
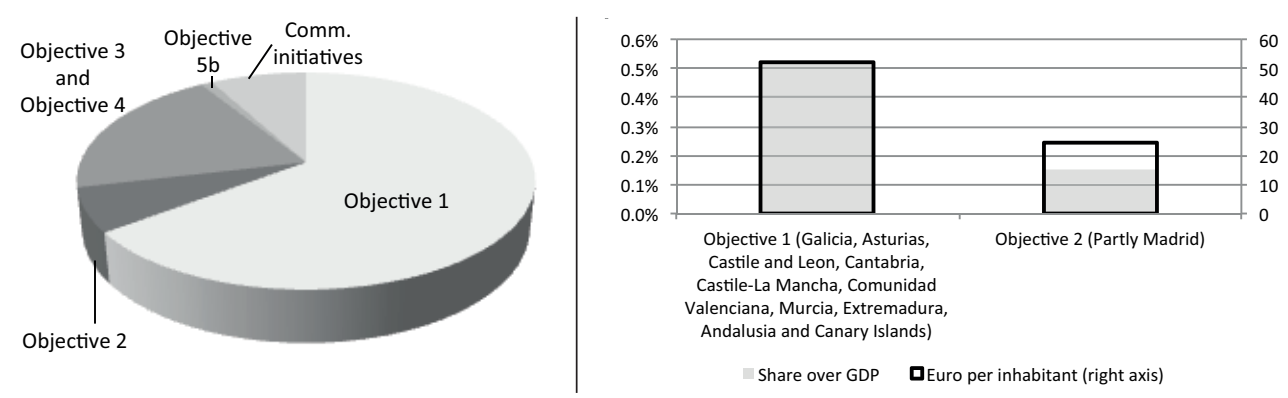

SOURCE: European Communities (1998) and INE.

The distribution of the ESF along Spanish regions during the next programming period (1994-1999) was fairly similar to the previous period. Again, the level of breakdown of the data collected for the share of the ESF allocated under objective 3 and 4 , which represent a significant share of total fund, does not allow observing the territorial distribution across different regions.

For the period 2000 2006, the former objective 5b was now included in the objective 2 while former objective 3 and 4 were merged in the new objective 3 . Otherwise, the budget, main objectives, co-financing rates and supervision remained almost unchanged. The focus of the ESF in Spanish objective 1 regions became more accused during these years. 
FIGURE 12

\section{DISTRIBUTION OF THE EUROPEAN STRUCTURAL FUNDS AMONG SPANISH REGIONS \\ (Programming period 2000-2006)}
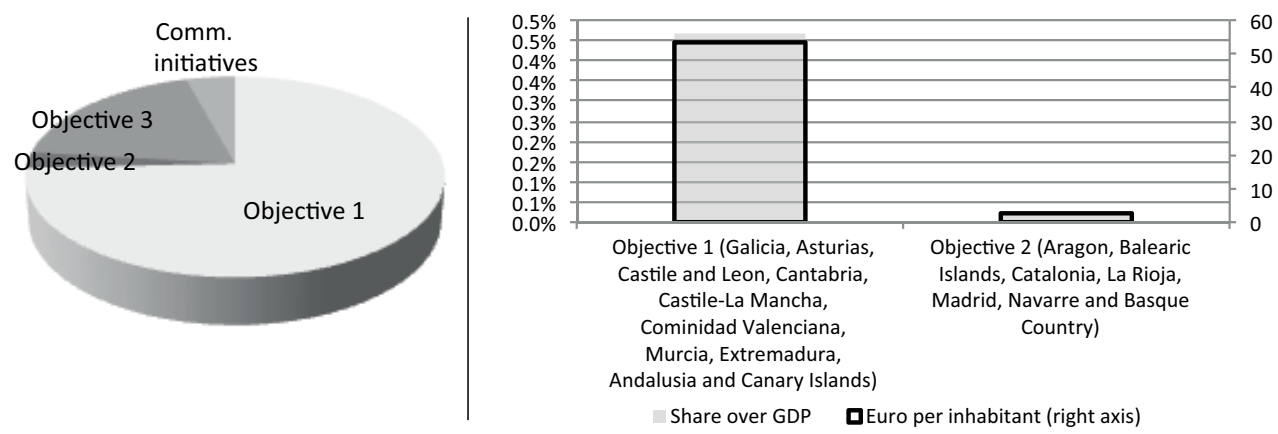

SOURCE: European Commission (2007c) and INE.

The programme 20072013 redesigned the objectives again in order to adapt the Structural Actions to the incorporation of new member states to the EU. Spain have 4 convergence regions (Galicia, Extremadura, Castilla la Mancha and Andalusia, with a GDP per head of less than $75 \%$ of the EU-25 average) and two phasing-out regions, plus two autonomous cities (Asturias, Ceuta, Melilla and Murcia, with a GDP per head of more than $75 \%$ of the EU-25 average but of less than $75 \%$ of the EU-15 average). The remaining are the three phasing-in regions (Castilla and Léon, Valencia and the Canary Islands, with a GDP per head of less than $75 \%$ of the EU-15 average in the period $2000-2006$ but more than $75 \%$ of the EU-15 average for the period 2007-2013) and the eight regional competitiveness and employment objective regions (Catalonia, Aragon, Madrid, la Rioja, Navarra, Basque Country, Cantabria and Balearic Islands, that have a GDP per head of more than $75 \%$ of the EU-25 average). More than half of the ESF was spent in Convergence objective regions during the period 20072010. 
FIGURE 13

\section{DISTRIBUTION OF THE EUROPEAN STRUCTURAL FUNDS AMONG SPANISH REGIONS \\ (Programming period 2007-2013)}
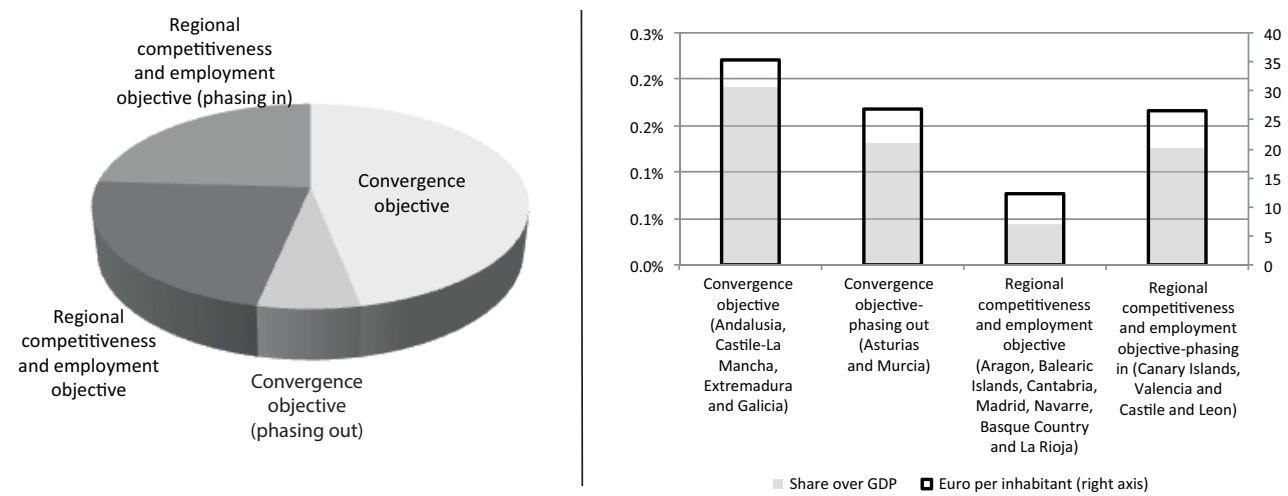

SOURCE: Anuario de Estadísticas del Ministerio de Trabajo e Inmigración (several years), retrieved at http:// www.empleo.gob.es/es/estadisticas/contenidos/anuario.htm.

\subsection{Fiscal decentralization and the European Social Fund in Spain}

The data presented so far represent the geographical distribution of the ESF according to the different administrative status that Spanish regions have been assigned in the several programming periods for the distribution of the Structural Actions. Nevertheless, these data are territorialized irrespectively of the level of the public administration that undertake the project financed by the ESF.

Generally, all levels of public administrations, local, regional and national, are involved in projects financed by the Structural Funds. But the Spanish economy has went through a fiscal decentralization process since its adhesion to the European Union which is not common to other EU Member States (Molero, 2002; GonzálezAlegre, 2010), and which is mainly associated with a transfer of fiscal autonomy from the central to the regional government. Due to this decentralization process, Spanish regional governments have also gained additional control over the administration of the Structural Funds at the cost of a lower importance of the central government.

The following chart illustrates this phenomenon for the case of the ESF. Immediately after joining the European Union, Spanish regional governments controlled around $10 \%$ of the ESF transfers from the EU to Spain, while during the last programming period this share has climbed to over $40 \%$. 
FIGURE 14

THE EUROPEAN SOCIAL FUND IN SPAIN: EVOLUTION OF THE SHARE OF THE ESF DISTRIBUTED TO REGIONAL GOVERNMENT TO THE TOTAL ESF ALLOCATED TO SPAIN

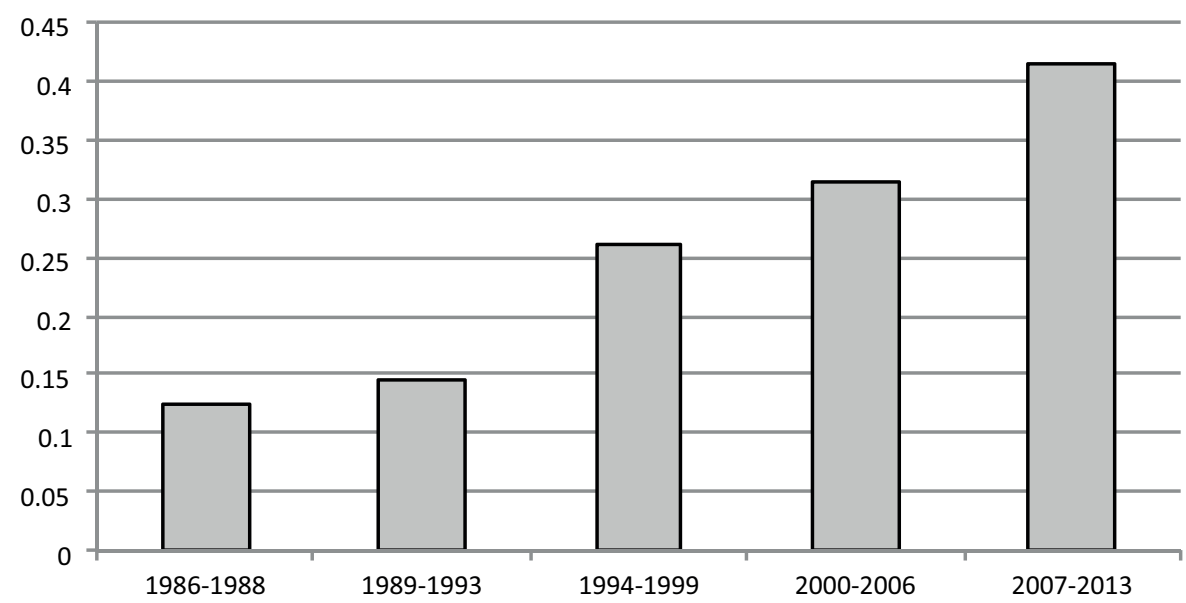

SOURCE: Self-elaboration from: 19952001 BADESPE; 20022010 Liquidacion presupuestos CCAA (database); 19871994 Informe sobre la financiación de las CCAA (yearbook).

But this decentralization process has not been symmetric. Spanish regional governments have not gained an homogeneous level of fiscal autonomy among them (González-Alegre, 2010b), and the process of transferring competencies from the central to regional governments have not been simultaneous either.

The Spanish Constitution discriminates between two types of regions: the socalled "historic nationalities" or regions with a high level of competencies, described in the article 143 of the Spanish Constitution ${ }^{3}$ and the ten remaining regions ${ }^{4}$ (and the two autonomous cities) that in principle assume a lower level of competencies, and are described in the article 151 of the Constitution. Each region has its own Statute of Autonomy that defines the activities in which the regional government is competent to legislate and govern. In practice, the regions with high levels of competencies experienced a higher level of decentralization in the beginning, but the differences have been reduced as long as the decentralization process has been taking place. The variety of fiscal competencies is also more heterogeneous among the group of "historic nationalities" (art. 143) than among the group of regions with low level of competencies.

\footnotetext{
${ }^{3}$ Andalusia, Basque Country, Canary Islands, Catalonia, Galicia, Navarre and Comunidad Valenciana.

${ }^{4}$ Aragon, Asturias, Balearic Islands, Cantabria, Castile-La Mancha, Castile and Leon, Comunidad de Madrid, Extremadura, Murcia and La Rioja.
} 
The following chart illustrates the extent to which this situation affects also the administration of the ESF. As there are no significant differences in the level of per capita income among both groups of regions, or in other macroeconomic variables nor geographical concentration, the differences observed respond mostly to the level of fiscal autonomy of the regional governments. We can observe how "historic nationalities" have administrated a larger share of the ESF in their territories in comparison to the remaining regions, both as a share of GDP and in per capita terms.

FIGURE 15
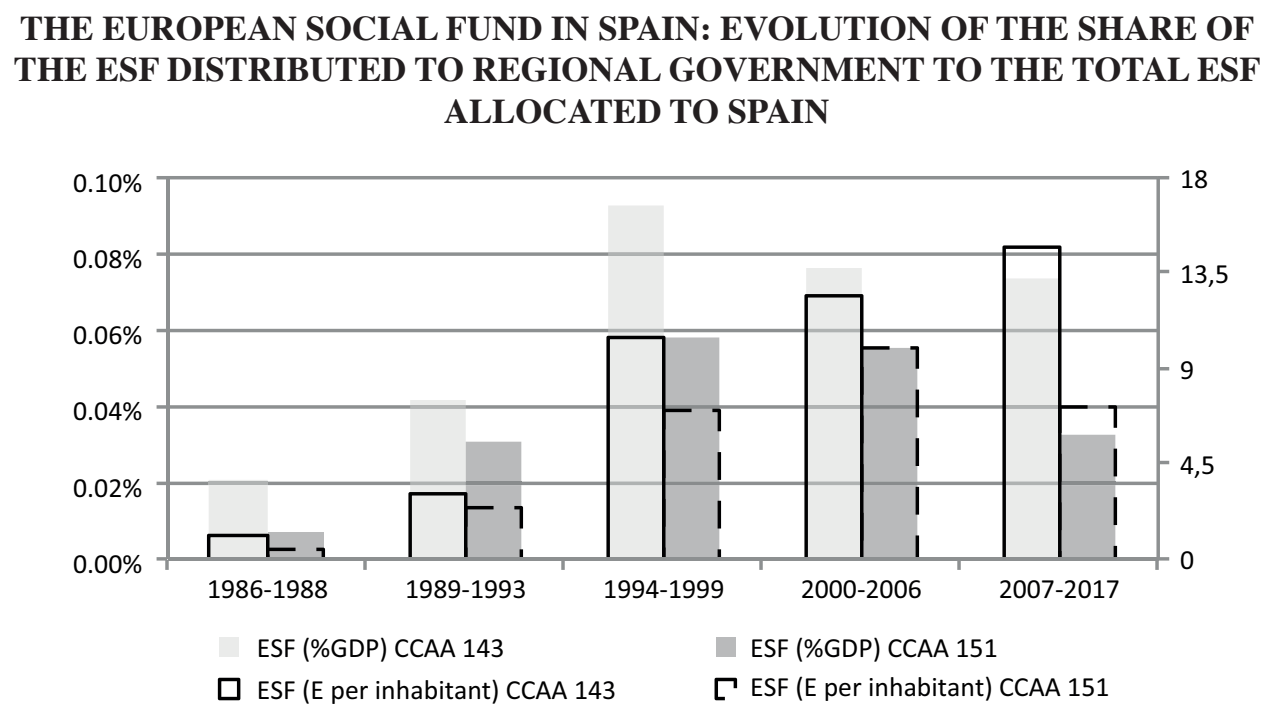

SOURCE: Self-elaboration from data shown in previous figures and INE.

\section{The effectiveness of active labor market policies. A review of some results}

In the early nineties, some studies begin to investigate the impact of active labor market policies on employment indicators by means of panel data models (Jackman et al., 1990; Layard et al., 1991; Zetterberg 1995) and find evidence, for OECD countries, that ALMPs are able to lower unemployment significantly. Other studies (OECD, 1993; Forslund and Krueger, 1997; Elmeskov et al., 1998), however, are critical with these results and argue that the relationship estimated might be upwards biased due to simultaneity bias between the dependent variable (usually unemployment) and the variable capturing public expenditure on ALMP. The subsequent studies address these critics updating the econometric models uses consequently, some (Nickell and Layard, 1999), for example, use one period lagged values of expenditure in ALMP, instead of the variables in levels. 
Later, in the early 2000s, the attention was focused towards the interaction of ALMP with variables capturing institutions of the labor market. (Blanchard and Wolfers, 2000; Basasini and Duval, 2009; Baccaro and Rei, 2005; Nickel et al., 2005; Sachs, 2012). These results are, again, relatively optimistic with respect to the capacity of ALMPs to creating employment. Nevertheless, their conclusions are no longer homogeneous across countries, as they discover that the effectiveness of ALMPs depend largely on the quality of the institutions of the labor market in the country under consideration.

Other studies use alternative methodological strategies. For example, those based in a matching-function approach (Hujer and Caliendo, 2000) use an indicator of the outflows from unemployment to employment as the dependent variable, which takes into account the displacement effects (crowding-out) of ALMP, that is, the substitution of workers provoked by the policy. Alternatively, other studies (Estevao, 2007) consider only the employment rate in the private sector. Their conclusions, in all cases covering panel data from OECD countries, are still that ALMP were very effective in increasing employment rates. Finally, another branch of the literature (Boone and van Ours, 2009) concludes that the impact on unemployment varies significantly among categories of ALMP in a panel data of 20 OECD countries (1985-1999).

\subsection{Studies based on regional-level data}

The number of studies estimating the impact of ALMP in a single country using panel data models for regional and local level variables has been quite prolific in some particular countries motivated by the availability of data and the focus of public policies. (In general the existence of macroeconomic estimations is usually correlated with the presence of microeconomic level evaluations).

In the early nineties, Sweden implemented an aggressive program of ALMP to fight rising unemployment. This policy generated a considerable amount of research (summarized in Calfmors et al., 2002). Regarding macroeconomic studies for regional panel data models, Calmfors and Skedinger (1995) estimate the impact of job creation and training policies in Swedish regions controlling for simultaneity bias. Their results are more optimistic with respect to job creation policies than for training policies. They estimate a panel data model in which the dependent variable is the unemployment rate and the ALMP are expressed as a ratio of treated individual over the total amount of "treatable" (unemployed) population. The set of control also included time and regional dummies and the national unemployment rate.

Another country in which research on the implementation of ALMPs has been extremely prolific in the view of the extended availability of data is Germany, in particular in the view of the importance that these policies reached after the reunification. Several studies (Hujer et al., 2002; Hujer et al., 2004) regress the total rate of job seekers on a vector containing the measure for ALMP and other 
explanatory variables, using panel data from 175 German labour districts. They represent ALMP as the accommodation ratios of the programs, which are defined as the sum of programme participants relative to the stock of job seekers. They use OLS and System GMM. They find a negative impact of ALMP on the rate of the job seekers in the short run, while the long-run effects are less clear. Hagen (2003) estimates, in addition, the impact of ALMPs on the flow from unemployment to employment (i.e. the matching function approach) and the impact on regular employment from regional-level data. His results are not extremely optimistic and he is able to find a negative impact of public training measures in the matching efficiency (the matching function approach was previously used by Boeri and Burda, 1996 for a panel of 76 Czech employment office districts and quarterly data).

There are very few studies relating the impact of ALMP to the level of fiscal decentralization. Lundin and Skedinger (2006) estimate, from microeconomic level data, the relationship between decentralization and effectiveness of ALMPs in Sweden. Using data from a governmental program in 1996, they conclude that decentralization stimulates the number of public initiatives, in particular those targeted to outsiders and relief works.

Altavilla and Caroleo (2006), estimates a dynamic panel data model and a panel VAR model using quarterly data from 20 Italian regions. Their results discover significant differences in the impact of ALMP between northern and southern regions, probably due to the differences in the economic structure of both groups of regions. The results in Altavilla and Caroleo (2011) reinforce their previous findings using factor-augmented vector autoregression techniques.

\section{Conclusions}

One of the main strategies recently decided in the hearth of the European Union in order to lower the level of unemployment and creating a more vigorous labour market, has been the provision of additional funds to be devoted to Active Labour Market Policies. The fiscal tool that channels these transfers towards the national and subnational levels of the public administration is, basically, the European Social Fund.

This paper explores the evolution of the distribution of the ESF since its creation, and its link with the main economic and political challenges that the European Union has faced. For that purpose, we describe briefly the main reforms that the Structural Funds, in general, and the European Social Fund, in particular, have suffered over the subsequent reforms, and analyze their impact in terms of geographical distribution of transfers.

With a particular focus on Spain, the paper also explores the geographical distribution of transfers across Spanish regions, and the response of the European Regional Policy to the process of fiscal decentralization that Spain has experienced since the eighties. In fact, Spain has been one of the main recipients of the ESF and, 
simultaneously, has experienced a process of fiscal decentralization, which has been implemented asynchronously over the different regions. For these reasons, Spain is a good scenario to analyze the capacity of adaptation of the Structural Funds to a changing scenario.

Finally, a review of the main econometric results explore to which extent the applied economics science has been able to demonstrate and measure the capacity of ALMPs to raise employment levels, both, from country-level and regionlevel data. Results, although optimistic, are not extremely conclusive and show excessive sensitiveness to methodological alterations and selection of explanatory variables.

\section{References}

[1] ALTAVILLA, C. and CAROLEO, F. E. (2006). "Evaluating the dynamic effects of active labor policies in Italy". LABOUR, CEIS, 20 (2), 349-382.

[2] ALTAVILLA, C. and CAROLEO, F. E. (2011). "Asymmetric effects of national-based active labour market policies". Centre for Studies in Economics and Finance (University of Naples). Working Paper no. 293.

[3] BACCARO, L. and REI, D. (2005). "Institutional Determinants of Unemployment in OECD countries: A Times-Series Cross-Section Analysis (1960-1998)". International Institute for Labor Studies. Geneva Discussion Paper no. 160.

[4] BACHE, I.; GEORGE, S. and BULMER, S. (2011). Politics in the European Union. Oxford: Oxford University Press.

[5] BASANINI, A. and DUVAL, R. (2009). "Unemployment institutions, and reform complementarities: re-assessing the aggregate evidence for OECD countries". Oxford Review of Economic Policy, 25 (1), 40-59.

[6] BLANCHARD, O. and WOLFERS, J. (2000). "The role of shocks and institutions in the rise of European unemployment: The aggregate evidence". Economic Journal, 110 (462), 1-33.

[7] BOERI, T. and BURDA, M. C. (1996). "Active labor market policies, job matching and the Czech miracle”. European Economic Review, 40, 805-817.

[8] BOONE, J. and VAN OURS, J. C. (2009). "Bringing unemployment back to work: Effective active labor market policies". De Economist, 157 (3), 293-313.

[9] CALMFORS, L.; FORSLUND, A. and HEMSTROM, M. (2002). "Does active labour market policy work? Lessons from the Swedish experiences". CESifo Working Paper no. 675

[10] CALMFORS, L. and SKEDINGER, P. (1995). "Does active labour market policy increase employment? Theoretical considerations and some empirical evidence from Sweden". Oxford Review of Economic Policy, 11 (1), 91-109.

[11] DOMÍNGUEZ GONZÁLEZ, A (1989). "El Fondo Social Europeo y España”. Economía y Sociología del Trabajo, 4-5, 59-72.

[12] ELMESKOV, J.; MARTIN, J. P. and SCARPETTA, S. (1998). "Key lessons for labour market reforms: evidence from OECD countries' experiences". Swedish Economic Policy Review, 5, 205-252. 
[13] ESTEVAO, M. (2007). "Labor policies to raise employment”. IMF Staff papers, 54 (1), 113-138.

[14] EUROPEAN COMMUNITIES (1998). The European Social Fund. An overview of the programming period 1994-1999. Luxembourg: Office for Official Publications of the European Communities (OPOCE) .ISBN 92-828-1136-0.

[15] EUROPEAN COMMISSION (2007). European Social Fund: 50 years investing in people. Luxembourg: Office for Official Publications of the European Communities ISBN 92-79-03357-3.

[16] EUROPEAN COMMUNITIES (2009). EU Budget 2008. Financial Report. Luxembourg: Office for Official Publications of the European Communities. ISBN 978-92-7912018-3.

[17] EUROPEAN COMMISSION (2007b). Cohesion policy 2007-13. Commentaries and official texts. Luxembourg: Office for Official Publications of the European Communities ISBN 92-79-03805-2.

[18] EUROPEAN COMMISSION (2007c). "18th Annual report on the implementation of the Structural Funds 2006”. Commission Staff Working Document COM(2007) 676 final.

[19] EUROPEAN COMMISSION (2013). Promoting jobs, inclusion and social policy as an investment. Luxembourg: Office for Official Publications of the European Communities. ISBN 978-92-79-24020-1.

[20] FORSLUND, A. and KRUEGER, A. (1997). "An evaluation of the Swedish Active Labor Market Policy: News and received wisdom”. NBER Chapters in: The Welfare State in transition: Reforming the Swedish Model. Cambridge, MA: NBER.

[21] GONZÁLEZ-ALEGRE， J. (2010). "Descentralización fiscal y transferencias intergubernamentales: la Política Regional Europea y las Comunidades Autónomas", in N. Bosch and A. Solé-Ollé (eds.), Informe sobre federalismo fiscal en España (ISBN 978-84-613-9114-1), Barcelona: IEB.

[22] GONZÁLEZ-ALEGRE, J. (2010b). "Decentralization and the Composition of Public Expenditure. Evidence from Spain”. Regional Studies, 44 (8).

[23] HAGEN, T. (2003). "Three approaches to the evaluation of Active Labour market policy in East Germany using regional data". ZEW (Centre for European Economic Research), Discussion Paper no. 03-27.

[24] HUJER, R.; BLIEN, U.; CALIENDO, M. and ZEISS, C. (2002). "Macroeconomic evaluation of Active Labour Market Policies in Germany. A dynamic approach using regional data". IZA Discussion Paper no. 616.

[25] HUJER, R. and CALIENDO, M. (2000). "Evaluation of active labour market policy: methodological concepts and empirical estimates". IZA (Institute for the Study of Labor). Discussion Paper no. 236.

[26[ HUJER, R.; CALIENDO, M. and ZEISS, C. (2004). "Macroeconomic evaluation of active labour market policy. A case study for Germany", in P. Descy and M. Tessaring (eds), Impact of education and training. Third report on vocational training research in Europe, OPOCE: Luxembourg.

[27] JACKMAN, R.; PISSARIDES, C. and SAVOURI, S. (1990). "Labour market policies and unemployment in the OECD". CEP (Centre for Economic Performance, LSE). Discussion Paper no. 11

[28] LAYARD, R.; NICKELL, S. and JACKMAN, R. (1991). Unemployment: Macroeconomic performance and the labor market. Oxford: Oxford University Press. 
[29] LUNDIN, M. and SKEDINGER, P. (2006). "Decentralisation of active labour market policy: The case of Swedish local employment service committees". Journal of Public Economics, 90 (4-5), 775-798.

[30] MOLERO, J. C. (2002). "Gasto público y federalismo fiscal en España. Periodo 19841998". MPRA Paper no. 8098.

[31] NICKELL, S. and LAYARD, R. (1999). "Labor market institutions and economic performance". Handbook of Labor Economics, vol. 3 (part c), pp. 3029-3084.

[32] NICKELL, S.; NUNZIATA, L. and OCHEL, W. (2005). "Unemployment in the OECD since the 1960s. What do we know?". The Economic Journal, 115 (1), 1-27.

[33] OECD (1993). Economic Outlook, July. Paris: OECD.

[34] SACHS, A. (2012). "What really drives unemployment? A Bayesian approach to determine the impact of institutions on the unemployment rate". Economic Bulletin, 32 (1), 1008-1019.

[35] ZETTERBERG, J. (1995). "Unemployment, Labour Market Policy and the Wage Bargaining System”. FIEF reprint series no. 99 (Trade Union Institute for Economic Research). 